\title{
KEBERLANJUTAN USAHATANI MANGGIS PROGRAM SERTIFIKAT PRIMA DI KECAMATAN KOTA AGUNG KABUPATEN TANGGAMUS
}

\author{
(The Sustainability of Mangosteen Farming Prima Certification Programme in Kota Agung- \\ Tanggamus District)
}

Biha Melati Sari, Bustanul Arifin, Yaktiworo Indriani

Jurusan Agribisnis, Fakultas Pertanian, Universitas Lampung, J1. Prof. Dr. Soemantri Brojonegoro No. 1 Bandar Lampung 35145, Telp. 0895353574668,e-mail: bihamelatisari@gmail.com

\begin{abstract}
This research aims to analyze the performance of mangosteen farming and certification benefits of sustainable mangosteen farming development in terms of economic, social, and environmental aspects. The location of the research is decided purposely in Terdana, Kota Agung, Tanggamus District. The samples of this research are 54 farmers whose products have been certified by prima. The performance of mangosteen farming is assessed by $R / C$ ratio. The results showed that the performance of mangosteen farming in terms of $R$ / C ratio per-ha was 6.91; it meant that each cash cost incurred by farmers of Rpl.00 then the farmers would receive revenue of Rp6.91 (could provide benefits on economical aspects). Prima Certification Program of mangosteen farming in Terdana, Kota Agung, Tanggamus district was quite sustainable in economic, social, and environmental aspects, in which sustainability index were 67.90; 71.02 and 72.82
\end{abstract}

Key words: farm income, mangosteen, prima certification, sustainability

\section{PENDAHULUAN}

Indonesia sebagai negara tropis kini melakukan spesialisasi produk yang berasal dari pertanian khususnya buah- buahan. Buah - buahan memiliki share yang cukup besar pada Pendapatan Domestik Bruto (PDB) hortikultura yaitu rata-rata sekitar 52 persen tiap tahunnya (Kementrian Pertanian 2014). Indonesia harus mampu menyajikan produk buahbuahan yang dapat bersaing dengan buah-buahan impor yang aman konsumsi.

Ketakutan konsumen akan residu pestisida dan pupuk kimia mengharuskan produk pangan yang tersedia terjamin mutunya. Jaminan mutu dan keamanan pangan bagi konsumen dalam mengkonsumsi suatu produk merupakan faktor penentu daya saing suatu produk terutama dalam perdagangan bebas. Strategi yang harus ditempuh antara lain mempromosikan buah - buahan dengan mengandalkan unggulan buah lokal spesifik Indonesia dan sertifikasi produk (Setyo 2009).

Salah satu sertifikasi produk yang diberikan pemerintah adalah Sertifikasi Prima untuk pangan segar. Sertifikat Prima terdiri dari 3 jenis yaitu Prima-3 yang berarti bahwa produk yang dihasilkan aman dikonsumsi (aman pestisida), Prima-2 berarti bahwa produk yang dihasilkan aman dikonsumsi (aman pestisida) dan bermutu (ada grading) dan Prima-1 artinya produk yang dihasilkan aman dikonsumisi (aman pestisida), bermutu dan ramah lingkungan (Badan Ketahanan Pangan Daerah Provinsi Lampung 2015).

Sertifikasi Prima diberikan oleh pemerintah daerah melalui Otoritas Kompeten Keamanan Pangan Daerah (OKKP-D) Provinsi Lampung dan bekerja sama dengan Laboratorium Penguji Mutu Hasil Pertanian Fakultas Pertanian Universitas Lampung yang telah terakreditasi KAN atas konsistensinya dalam menerapkan SNI ISO/IEC 17025:2008. Provinsi Lampung merupakan salah satu daerah yang telah memberikan Sertifikasi Prima-3 ini. Provinsi Lampung sendiri telah memberikan 21 Sertifikat Prima-3 untuk komoditas nanas, manggis, belimbing, buah naga, jambu mutiara, tomat, dan wortel serta 2 registrasi produk untuk produk beras analog berbahan baku singkong (Badan Ketahanan Pangan Daerah Provinsi Lampung 2015).

Provinsi Lampung merupakan salah satu sentra penghasil manggis di Indonesia yang berpusat di Kecamatan Kota Agung, Kabupaten Tanggamus. Kabupaten Tanggamus menyumbang 83 persen dari total produksi Provinsi Lampung (Kementrian Pertanian 2017). Lahan penanaman manggis di Kecamatan Kota Agung terpusat di dua desa/pekon yaitu Pekon Terdana. Pekon Terdana dijadikan kebun percontohan oleh Dinas Tanaman Pangan dan Hortikultura Kabupaten Tanggamus dan telah 
mendapatkan Sertifikat Prima-3 untuk manggisnya (Balai Penyuluhan Pertanian Kecamatan Kota Agung 2015).

Pelaksanaan Sertifikasi Prima-3 memiliki syarat umum yang harus dipenuhi oleh kelompok atau pemohon yang akan mengajukan sertifikasi. Syarat umum ini meliputi kelompok atau pemohon telah menerapkan GAP-SOP (Good Agricultural Practices-Standart Operating Procedure). Sertifikasi Prima-3 dapat memberikan manfaat yang besar kepada petani, akan tetapi belum semua anggota kelompok tani di Kecamatan Kota Agung menerapkan dengan baik dan benar GAP-SOP ini. Hal inilah yang menyebabkan banyak anggota kelompok tani di Kecamatan Kota Agung yang belum merasakan manfaat dari Sertifikasi Prima-3 untuk usahatani manggisnya, sehingga jumlah petani yang mendapatkan sertifikasi masih sedikit dan belum berkelanjutan. Penelitian ini bertujuan untuk mengkaji keberlanjutan usahatani manggis program Sertifikasi Prima-3 dari aspek ekonomi, sosial, dan lingkungan.

\section{METODE PENELITIAN}

Metode penelitian yang digunakan adalah metode Sensus. Menurut Arikunto (2002), apabila subjek penelitian kurang dari 100 unit (orang), maka lebih baik diambil semua sehingga penelitian ini merupakan penelitian populasi. Penelitian ini dilakukan di Pekon Terdana, Kecamatan Kota Agung, Kabupaten Tanggamus. Pemilihan lokasi dilakukan secara sengaja (purposive) dengan pertimbangan bahwa Pekon Terdana merupakan satu-satu nya pekon yang telah mendapatkan sertifikasi dari OKKPD Provinsi Lampung.

Pengumpulan data dilaksanakan pada bulan Agustus - September 2017 dengan jumlah 54 petani responden. Data yang dikumpulkan dalam penelitian ini terdiri dari data primer dan data sekunder. Metode analisis yang digunakan dalam penelitian ini adalah metode kuantitatif dan kualitatif.

Keberlanjutan usahatani manggis program Sertifikasi Prima dari aspek ekonomi, sosial dan lingkungan menggunakan kaidah GAP (Good Agriculture Practice) sebagai dasar dari pelaksanaan program sertifikasi Prima. Kaidah GAP merupakan panduan yang mencakup penerapan teknologi yang ramah lingkungan, penjagaan kesehatan, pencegahan penularan OPT (Organisme Pengganggu Tanaman) dan prinsip
Traceability yaitu suatu produk dapat ditelusuri asal usulnya dari pasar sampai kebun. Kaidah GAP terdiri dari 54 titik kendali kegiatan yang sangat dianjurkan dan menjadi indikator dalam penelitian ini. Indikator tersebut dikelompokkan berdasarkan indikator ekonomi(4 indikator) sosial (18 indikator) dan lingkungan (32 indikator) yang diukur menggunakan skala likert dengan skor dari 1 sampai 3 , dimana $1=$ jika tidak sesuai anjuran, $2=$ jika cukup sesuai anjuran dan $3=$ jika sesuai anjuran. Seluruh indikator telah diuji nilai validitas dan reliabilitasnya sehingga indikator tersebut benar-benar dapat digunakan mengukur yang ingin diukur dalam penelitian ini.

Pada aspek ekonomi keberlanjutan usahatani manggis program Sertifikasi Prima dihitung pendapatan usahatani manggisnya. Menurut Soekartawi (1995) untuk menghitung pendapatan, digunakan rumus berdasarkan persamaan satu (1) berikut:

$\mathrm{Pd}=\mathrm{Y} . \mathrm{Py}-\mathrm{X} . \mathrm{Px}$.

Keterangan:

$\mathrm{Pd}=$ Pendapatan usahatani $(\mathrm{Rp})$

$\mathrm{Y}=$ Total produksi $(\mathrm{Rp})$

Py $=\operatorname{Harga}(\mathrm{Rp})$

$\mathrm{X}=$ Input produksi

$\mathrm{Px}=$ Harga Input

Hasil dari penilaian indikator ekonomi, sosial dan lingkungan ini kemudian dilakukan klasifikasi terhadap status berkelanjutan usahatani yang dilakukan oleh petani., maka dilakukan perhitungan indeks keberlanjutan (IK) . Menurut Thamrin et.al. (2007), Indeks keberlanjutan digunakan untuk melihat posisi keberlanjutan dari usahatani yang dilakukan. Indeks keberlanjutan ditentukan berdasarkan persamaan dua (2) berikut.

$\mathrm{IK}=\frac{\text { skor yang diperoleh }}{\text { skor maksimum }}$.

Skala Indeks keberlanjutan dihitung dari total skor setiap petani keberlanjutan terletak pada 0100 persen. Indeks keberlanjutan dihitung dari total skor setiap petani. Status keberlanjutan terbagi menjadi empat kategori, yaitu:

1. Nilai indeks 0-25 : tidak keberlanjutan

2. Nilai indeks 25-50: kurang berkelanjutan

3. Nilai indeks 50-75 : cukup berkelanjutan

4. Nilai indeks 75-100 : berkelanjutan 


\section{HASIL DAN PEMBAHASAN}

\section{Keadaan Umum Responden}

Usahatani manggis si Pekon Terdana Kecamatan Kota Agung Kabupaten Tanggamus dijadikan kebun percontohan oleh Dinas Tanaman Pangan dan Hortikultura Kabupaten Tanggamus dan telah mendapatkan. Sertifikasi Prima-3 untuk manggisnya yang berarti bahwa manggis yang dihasilkan telah bebas dari bahan kimia berbahaya. Petani manggis di Pekon Terdana berada pada usia produktif sebanyak 47 responden $(87 \%)$ dan petani lansia sebanyak 7 responden $(13 \%)$ yang sebagian besar hanya lulus SD sebanyak 24 responden (45\%), SMP sebanyak 11 responden (20\%) serta SMA sebanyak 19 responden (35\%). Pengalaman berusahatani petani manggis berada pada rentang 5-15 tahun sebanyak 23 responden $(42,59 \%)$ dan sebanyak 46 responden tidak memiliki pekerjaan sampingan $(85,3 \%)$ namun 8 responden ada 7 yang bekerja sampingan sebagai buruh, pedagang, tukang bangunan dan tukang kebun $(14,7 \%)$. Petani Sertifikasi Prima memiliki rata-rata lahan sebesar 0,38 ha dengan persentase paling besar pada luas lahan dengan rentang $0,25-0,50$ ha dan rata-rata pohon manggis sebanyak 44 pohon.

\section{Keberlanjutan Usahatani Manggis Program Sertifikasi Manggis dari Aspek Ekonomi}

Keberlanjutan usahatani manggis sertifikat prima secara ekonomi diukur berdasarkan indikator pihak penentu harga; lembaga yang bekerja sama dengan petani; penentuan harga berdasarkan mutu dan penentuan harga secara tawar menawar rata-rata skor keberlanjutan dapat dilihat pada Tabel 1.

Tabel 1. Rata-rata skor keberlanjutan usahatani manggis usahatani dari aspek ekonomi

\begin{tabular}{llc}
\hline & \multicolumn{1}{c}{ Indikator } & Rata-Rata Skor \\
\hline 1. & Pihak penentu harga manggis & 2,14 \\
2. & $\begin{array}{l}\text { Lembaga yang bekerja sama } \\
\text { dengan petani }\end{array}$ & 2.25 \\
3. & $\begin{array}{l}\text { Penentuan harga berdasarkan } \\
\text { mutu/ grade manggis }\end{array}$ & 1,48 \\
4. $\quad \begin{array}{l}\text { Penentuan harga melalui proses } \\
\text { tawar menawar }\end{array}$ & 2,26 \\
\hline Total Skor & 8,14 \\
Indeks keberlanjutan & 67,9 \\
Keterangan & Cukup \\
& Berkelanjutan \\
\hline
\end{tabular}

Keterangan:

Skor $1=$ tidak sesuai anjuran

Skor 2 = cukup sesuai anjuran

Skor $3=$ sesuai anjuran
Skor penilaian indeks keberlanjutan dari aspek ekonomi sebesar 67,90 berarti bahwa program Sertifikat Prima cukup berkelanjutan untuk usahatani manggis di Pekon Terdana. aspek ekonomi cukup terhadap keberlanjutan usahatani manggis. Pihak yang menenutukan harga manggis di pekon terdana adalah pihak pembeli/tengkulak, konsumen dan harga berdasarkan harga di pasar sehingga terdapat perbedaan harga bagi petani yang menjual ke tengkulak, konsumen, dan pedagang besar dipasar. Petani responden dominan memilih menjual hasil panen manggisnya kepada tengkulak dengan persentase sebesar 56\% (30 responden) dengan harga jual Rp13.000/kg sedangkan petani yang menjual hasil panen manggisnya ke pedagang besar adalah sebesar 35\% (19 Responden ) dengan harga jual Rp15.000/kg dan petani yang menjual langsung ke konsumen adalah sebesar 9\% (5 responden ) dengan harga jual Rp17.000/kg. Petani mengantarkan hasil panenan kepada tengkulak karena proses jual beli dilakukan di tempat tengkulak yang letaknya tidak jauh dari letak kebun manggis .

Penentuan harga berdasarkan mutu biasanya dilakukan pada petani yang menjual manggisnya kepada pedagang besar. Pedagang besar menentukan bemutu manggis yang baik, sedang dan rendah dengan kisaran harga Rp15.000,- untuk manggis yang bermutu baik, Rp14.000,- untuk manggis yang bermutu sedang dan Rp13.000,untuk manggis yang bermutu rendah. Petani yang menjual manggisnya ke tengkulak dan konsumen diberikan harga yang sama dengan sistem borongan selain itu, penentuan harga berdasarkan tawar menawar hanya dilakukan pada petani yang menjual manggisnya ke konsumen

Lembaga pemasaran yang bekerja sama dengan petani manggis sertiifikat prima yaitu koperasi dan Dinas Ketahanan Pangan dan Hortikultura Kabupaten Tanggamus. Sertifikasi manggis memberikan kemudahan akses ekonomi kepada petani. Petani manggis yang telah tersertifikasi dapat menjual produknya kepada konsumen atau supermarket dengan adanya kepastian harga dan keterjaminan produk.

\section{Analisis Pendapatan Usahatani}

Pendapatan usahatani merupakan nilai produksi dikurangi dengan biaya-biaya yang dikeluarkan selama satu tahun/periode. Rata-rata pendapatan usahatani dan $\mathrm{R} / \mathrm{C}$ rasio petani manggis Sertifikasi Prima dapat dilihat pada Tabel 2. 
Tabel 2. Rata-rata pendapatan usahatani dan R/C rasio petani manggis Sertifikasi Prima per hektar

\begin{tabular}{|c|c|c|c|c|c|}
\hline No & Uraian & Satuan & Jumlah & Harga $(\mathrm{Rp}) /$ satuan & Nilai (Rp) \\
\hline \multirow[t]{2}{*}{1.} & Penerimaan & & & & \\
\hline & Produksi & $\mathrm{Kg}$ & $8.000,00$ & $15.037,04$ & $120.296 .296,30$ \\
\hline \multirow[t]{14}{*}{2.} & Biaya Tunai & - & - & - & - \\
\hline & Pupuk Urea & $\mathrm{Kg}$ & 109 & 1.900 & $207.944,44$ \\
\hline & Pupuk SP-36 & $\mathrm{Kg}$ & 235 & 3.600 & $846.000,00$ \\
\hline & Pupuk NPK & $\mathrm{Kg}$ & 160 & 3.900 & $622.555,56$ \\
\hline & Pupuk Kandang & $\mathrm{Kg}$ & 400 & 200 & $80.000,00$ \\
\hline & Biaya Angkut & $\mathrm{Rp}$ & & & $816.666,67$ \\
\hline & TK Luar Keluarga & $\mathrm{Rp}$ & & & $7.613 .194,00$ \\
\hline & Total Biaya Tunai & $\mathrm{Rp}$ & & & $10.186 .361,00$ \\
\hline & II. Biaya Diperhitungkan & & & & \\
\hline & Sewa lahan & $\mathrm{Rp}$ & & & $3.000 .000,00$ \\
\hline & Penyusutan Alat & $\mathrm{Rp}$ & & & $125.796,30$ \\
\hline & TK Dalam Keluarga & $\mathrm{Rp}$ & & & $2.373 .379,63$ \\
\hline & Total Biaya Diperhitungkan & $\mathrm{Rp}$ & & & $5.499 .175,93$ \\
\hline & Total Biaya & $\mathrm{Rp}$ & & & $15.685 .537,04$ \\
\hline \multirow[t]{2}{*}{3.} & Pendapatan Atas Biaya Tunai & $\mathrm{Rp}$ & & & $110.276 .601,85$ \\
\hline & Pendapatan Atas Biaya Total & $\mathrm{Rp}$ & & & $104.777 .425,93$ \\
\hline \multirow{2}{*}{4.} & R/C Atas Biaya Tunai & & & & 6,91 \\
\hline & R/C Atas Biaya Total & & & & 12,60 \\
\hline
\end{tabular}

Berdasarkan Tabel 2 rata-rata pendapatan per hektar per tahun atas biaya tunai untuk petani sertifikat sebesar Rp110.276.601,85 sedangkan rata-rata pendapatan atas biaya total petani sertifikat sebesar Rp104.777.425,93. R/C atas biaya tunai petani manggis sertifikat sebesar 6,91 yang artinya setiap biaya tunai yang dikeluarkan petani sebesar Rp1,00 maka petani tersebut akan memperoleh penerimaan sebesar Rp6,91 dan R/C atas biaya total petani manggis sertifikat sebesar 12,60 yang artinya setiap biaya total yang dikeluarkan petani sebesar Rp1,00 maka petani tersebut akan memperoleh penerimaan sebesar Rp12,60. Petani manggis sertifikat di pekon Terdana Kecamatan Kota Agung Kabupaten Tanggamus ini memperoleh R/C lebih besar dari satu yang artinya usahatani manggis sertifikat cukup menguntungkan untuk dijalankan dan berdasarkan aspek ekonomi usahatani manggis telah berkelanjutan.

\section{Keberlanjutan Usahatani Manggis Program Sertifikasi Manggis dari Aspek Sosial}

Keberlanjutan usahatani manggis sertifikat prima secara sosial diukur berdasarkan indikator frekuensi kehadiran petani; keterlibatan petani dalam kegiatan; keaktifan petani dalam diskusi;

keikutsertaan petani memantau kegiatan; sumbangan uang yang diberikan. Berdasarkan indikator tersebut, digunakan 18 pertanyaan untuk menilai praktik pengelolaan usahatani manggis yang berkelanjutan dari aspek sosial. Skor penilaian indeks keberlanjutan dari aspek sosial sebesar 77,06 yang berarti bahwa program Sertifikat Prima dapat berkelanjutan untuk usahatani manggis di Pekon Terdana. Usahatani manggis yang berkelanjutan dari aspek sosial berkaitan dengan kualitas hidup petani yang bekerja dan hidup dipertanian serta masyarakat disekitarnya.

Adanya sertifikasi manggis menyebabkan banyak para lembaga/institusi yang bekerjasama dengan kelompok tani seperti koperasi, Badan Ketahanan Pangan Daerah Provinsi Lampung, Supermarket di Kota agung, dan Chandra Department Store untuk mengadakan pembinaan dan penyuluhan dan kerjasama perdagangan, hal ini menyebabkan kegiatan kelompok tani meningkat, sehingga banyak kegiatan kelompok tani yang dapat diikuti oleh petani. Petani manggis sertifikasi sebagian besar aktif menghadiri kegiatan kelompok tani. Kelompok tani pada umumnya mengadakan pertemuan setiap dua bulan sekali.

Pertemuan tersebut biasanya digunakan untuk membahas perencanaan kegiatan yang akan diadakan. Pertemuan rutin kelompok tani ini juga dimanfaatkan oleh petani tidak hanya membahas perencanaan kegiatan tetapi juga melakukan kegiatan lain yang diadakan oleh pemerintah atau perusahaan seperti penyuluhan, pelatihan dan pembinaan. 
Tabel 3. Rata-rata skor keberlanjutan usahatani manggis dari Aspek Sosial

\begin{tabular}{|c|c|}
\hline Indikator & Rata-Rata Skor \\
\hline Frekuensi Kehadiran Petani dalam Kegiatan Kelompok Tani & 2,15 \\
\hline 1. Pelatihan kelompok tani tentang perlindungan tanaman & 2,17 \\
\hline 2. Pemberdayaan masyarakat dalam kegiatan pertanian & 1,48 \\
\hline 3. Pelatihan manajemen dan teknologi agribisnis pada usahatani manggis & 2,26 \\
\hline 4. Keaktifan dalam kegiatan kelompok tani & \\
\hline \multicolumn{2}{|l|}{ Keterlibatan petani dalam kegiatan kelompok tani } \\
\hline 1. Keterlibatan petani dalam rapat organisasi yang diikuti & 2,11 \\
\hline 2. Keterlibatan petani dalam kegiatan penyuluhan yang dilaksanakan organisasi Keterlibatan & 1,61 \\
\hline petani dalam kegiatan penyuluhan yang dilakukan oleh penyuluh & 2,35 \\
\hline 3. Pertemuan dengan kelompok tani (minimal 1 bulan) & 2,43 \\
\hline 4. Partisipasi dalam kegiatan sosial dan domestik & 2,22 \\
\hline \multicolumn{2}{|l|}{ Keaktifan petani dalam diskusi kelompok tani } \\
\hline 1. Diskusi berkaitan dengan masalah usahatani manggis bersama kelompok & 2,11 \\
\hline 2. Keberanian mengemukakan pendapat dalam diskusi & \\
\hline \multirow[t]{2}{*}{ 3. Penyimpanan catatan tentang informasi yang didapat dari setiap kegiatan kelompok tani } & 2,35 \\
\hline & 2.44 \\
\hline Sumbangan Uang yang Diberikan Petani Kepada Kelompok Tani & 2,41 \\
\hline 1. Iuran rutin untuk kegiatan kelompok tani & 2,37 \\
\hline 2. Iuran bantuan bagi kelompok tani yang membutuhkan & 1,93 \\
\hline \multicolumn{2}{|l|}{ 3. Iuran sukarela untuk keperluan yang kegiatan kelompok tani } \\
\hline Keikutsertaan Petani Memantau Kegiatan Kelompok Tani & 2,33 \\
\hline 1. Keaktifan petani dalam pemantauan dan evaluasi awal kegiatan organisasi & 2,39 \\
\hline 2. Keaktifan petani dalam pemantauan dan evaluasi saat kegiatan berlangsung & 2,22 \\
\hline 3. Keaktifan petani dalam pemantauan dan evaluasi akhir kegiatan organisasi & \\
\hline Total & 39,33 \\
\hline Indeks keberlanjutan & 71,02 \\
\hline Keterangan & Berkelanjutan \\
\hline
\end{tabular}

Keterangan:

Skor $1=$ tidak sesuai anjuran

Skor 2 = cukup sesuai anjuran

Skor 3 = sesuai anjuran

Petani mendapatkan banyak manfaat dari pertemuan kelompok tani ini, seperti meningkatkan pengetahuan mengenai inovasi dan cara penerapannya, informasi pasar manggis, perkembangan harga manggis, informasi mengenai kegiatan-kegiatan apa saja yang akan dilakukan oleh kelompok tani serta menjalin silaturahmi dan komunikasi dengan petani lain. Sebagian besar petani manggis sertifikat aktif mengikuti kegiatan - kegiatan kelompok tani, bahkan petani sering kali tidak hanya berperan sebagai peserta kegiatan tersebut tetapi juga ikut aktif sebagai pelaksana dan ikut mengontrol kegiatan.

Petani manggis sertifikasi Sebagian besar aktif untuk memberikan ide, gagasan dan saran saat mengikuti rapat untuk kemajuan kelompok tani. Adanya program sertifikasi ini menjadi ajang diskusi bagi para petani manggis. Sumbangan yang diberikan petani berupa iuran rutin yang wajib dibayarkan setiap awal tahun sebesar Rp100.000, iuran sukarela yang dibayarkan setiap kegiatan dan tidak ditentukan jumlahnya, serta iuran bantuan untuk petani yang sedang sakit atau membutuhkan bantuan.
Petani aktif mengikuti rapat kegiatan dan mengikuti evaluasi, petani manggis sertifikat dapat melatih kemampuan berorganisasi melalui kegiatan yang dilakukan. Adanya sertifikasi manggis menggugah para lembaga/institusi yang bekerjasama dengan kelompok tani untuk mengadakan pembinaan dan penyuluhan, hal ini menyebabkan kegiatan kelompok tani meningkat, sehingga banyak kegiatan kelompok tani yang dapat diikuti oleh petani . Usahatani yang berkelanjutan memberikan nilai tambah pertanian bagi lebih banyak anggota masyarakat melalui lebih banyak penggunaan tenaga kerja yang tersedia. Perlakuan yang layak terhadap pekerja dan memilih membeli bahanbahan secara lokal juga merupakan elemen keberlanjutan sosial untuk usahatani manggis.

\section{Keberlanjutan Usahatani Manggis Program Sertifikasi Manggis dari Aspek Lingkungan}

Keberlanjutan usahatani manggis sertifikat prima secara sosial diukur berdasarkan indikator budidaya tanaman sehat, pelestarian dan pemanfaatan musuh alami, pengamatan agroekosistem secara rutin, dan petani menjadi ahli PHT dan manajer dikebunnya, cara budidaya dan 
kearifan lokal. Berdasarkan indikator tersebut, digunakan 32 pertanyaan untuk menilai keberlanjutan usahatani manggis dari aspek lingkungan. Rata-rata skor keberlanjutan usahatani manggis dari aspek lingkungan dapat dilihat pada Tabel 4.

Berdasarkan Tabel 4 Skor penilaian indeks keberlanjutan dari aspek lingkungan sebesar 72,82 yang berarti berarti bahwa program Sertifikat Prima dapat berkelanjutan untuk usahatani manggis di Pekon Terdana. Pelaksanaan usahatani manggis dari aspek lingkungan telah layak secara ekologis dan sedikit memberikan dampak negatif terhadap ekosistem alam.

Petani manggis sebagian besar masih menggunakan pupuk kimia walaupun dosis yang digunakan dalam dosis kecil. Usahatani manggis yang berkelanjutan secara lingkungan dalam pelaksanaannya sudah mengurangi penggunaan bahan kimia sampai minimum, melindungi sumberdaya alam seperti tanah, air, dan agen hayati yang memberikan sumbangan terhadap perlindungan modal alami. Pupuk sintetik dalam usahatani manggis yang berkelanjutan dapat digunakan untuk melengkapi input alami jika diperlukan.

Tabel 4. Rata-rata skor keberlanjutan usahatani manggis dari Aspek Lingkungan

\begin{tabular}{|c|c|c|}
\hline & Indikator & Rata-rata Skor \\
\hline \multicolumn{3}{|c|}{ Budidaya Tanaman Sehat } \\
\hline 1 & Pemilihan dan penaman benih yang sehat dan sesuai kondisi setempat & 2,13 \\
\hline 2 & Cara mengatasi hama dan penyakit tanaman manggis & 1,85 \\
\hline 3 & Penggunaan pupuk kimia sedikit demi sedikit menurun & 2,11 \\
\hline 4 & Pergeseran penggunaan pestisida kimiawi ke arah penggunaan pestisida nabati & 2,24 \\
\hline \multicolumn{3}{|c|}{ Pelestarian dan Pemanfaaan Musuh Alami } \\
\hline 1 & Petani mengenali jenis-jenis OPT pada usahatani manggis & 2,35 \\
\hline 2 & Petani mengetahui gejala-gejala yang ditimbulkan OPT pada usahatani manggis & 2,07 \\
\hline 3 & Cara pengendalian OPT pada usahatani manggis & 2,28 \\
\hline 4 & Keterampilan dalam mengenali jenis-jenis musuh alami & 2,67 \\
\hline 5 & Pengetahuan tentang keberadaan musuh alami agar tidak musnah & 2,46 \\
\hline 6 & Mengurangi tindakan-tindakan yang dapat mematikan perkembangan musuh alami & 2,37 \\
\hline 7 & Pestisida yang digunakan harus terdaftar dan diizinkan oleh Mentan RI & 2,19 \\
\hline 8 & Pestisida harus disimpan dalam kemasan aslinya & 2,63 \\
\hline 9 & Penggunaan pestisida sesuai anjuran, tidak boleh menjelang panen atau saat panen & 2,20 \\
\hline 10 & Wadah bekas pestisida harus dirusak & 2,35 \\
\hline 11 & Wadah bekas pestisida harus dibuang pada tempat yang aman. & 2,19 \\
\hline \multicolumn{3}{|c|}{ Pengamatan Agroekosistem Secar Rutin } \\
\hline 1 & Keterampilan dalam pengamatan dan analisis agroekosistem & 1,70 \\
\hline 2 & Mengamati tanaman, tanah, air, cuaca, hama, penyakit, tikus, gulma dan musuh alami. & 1,91 \\
\hline 3 & Penerapan teknologi PHT dan keseimbangan ekosistem relatif tetap terjaga & 1,74 \\
\hline \multicolumn{3}{|c|}{ Petani Menjadi Ahli PHT dan Manajer di Kebunnya } \\
\hline 1 & Pengetahuan dalam penyemprotan pestisida untuk mengendalikan serangan OPT & 1,59 \\
\hline 2 & Pengetahuan dalam pembuatan pestisida nabati & 2,30 \\
\hline \multicolumn{3}{|c|}{ Cara Budidaya } \\
\hline 1 & Pembuatan Persemaian & 1,83 \\
\hline 2 & Pembersihan Lahan & 2,57 \\
\hline 3 & Pembuatan Bedengan & 1,91 \\
\hline 4 & Penanaman & 2,04 \\
\hline 5 & Sanitasi Lahan & 2,04 \\
\hline 6 & Pemupukan & 2,22 \\
\hline 7 & Pemanenan & 2,22 \\
\hline 8 & Penyortiran dan Pengkelasan Buah & 1,93 \\
\hline \multicolumn{3}{|c|}{ Kearifn Lokal } \\
\hline 1 & Cara mendapatkan bibit manggis & 2,24 \\
\hline 2 & Penggunaan pola tanam satu alur atau pola tanam ganda (jejar legowo) & 1,98 \\
\hline 3 & Cara pembukaan lahan & 2,06 \\
\hline 4 & Penggunaan pupuk kandang & 1,39 \\
\hline \multicolumn{2}{|c|}{ Total } & 77,50 \\
\hline \multicolumn{2}{|c|}{ Indeks Keberlanjutan } & 72,82 \\
\hline \multicolumn{2}{|c|}{ Keterangan } & Berkelanjutan \\
\hline
\end{tabular}


Petani manggis sertifikasi sudah melakukan pelestarian dan pemanfaatan musuh alami,seperti mengenali jenis-jenis OPT, pengendalian OPT, penggunaan pestisida yang dianjurkan dan wadah pestisida harus dibuang pada tempat yang aman sudah sesuai dengan anjuran dalam pedoman Sertifikasi Prima dilakukan untuk tanaman manggisnya. Petani manggis juga sering mengikuti penyuluhan tentang hama dan penyakit pada tanaman manggis serta cara pemberantasannya.

Petani manggis sertifikasi sudah mengerti tata cara pengamatan agroekosistem, seperti mengamati tanaman, tanah, air , cuaca, hama, penyakit, tikus, gulma dan musuh alami, juga menganalisis keadaan agroekosistem dan membuat keputusan untuk pengelolaan selanjutnya serta penerapan teknologi PHT dan keseimbangan ekosistem usahatani manggis relatif tetap terjaga.

Petani manggis sertifikasi telah mengerti mengaplikasikan hasil pengamatan kepada tanaman sesuai dengan anjuran pedoman sertifikasi. Petani manggis sertifikasi juga sudah mampu melihat interaksi antara tanaman, Organisme Pengganggu Tanaman (OPT), musuh alami dan sumberdaya hayati di lingkungan tempat tinggal dan kebun manggis serta penerapan teknologi yang dapat diaplikasikan untuk mengatasi OPT pada tanaman manggisnya. Petani sudah mengetahui cara penyemprotan pestisida, pembuatan pestisida nabati dan kompos untuk digunakan pada kebun manggis. Adanya program sertifikasi pada produk manggisnya, secara tidak langsung mengajarkan petani untuk menjadi manajer di kebunnya sendiri. Petani dapat bijak menentukan tindakan yang harus dilakukan dalam mengelola kebunnya. Petani manggis sudah melakukan tata cara budidaya yang benar sehingga hasil produksi dapat meningkat. Petani manggis yang mengikuti sertifikasi juga dibantu melalui pedoman sertifikasi untuk melakukan tata cara bududaya yang benar dan bebas dari bahan kimia berbahaya sehingga produk yang dihasilkan terjamin kualitas dan kuantitasnya.

Petani manggis di Pekon Terdana masih mengikuti tradisi turun-temurun yang ada sejak dahulu seperti penggunaan pola tanam, teknik pembukaan lahan hingga cara budidayanya. Petani manggis di Pekon Terdana termasuk petani yang terbuka akan inovasi baru dan teknologi baru, namun petani tidak meninggalkan tradisi yang sejak dahulu sudah ada seperti pembukaan lahan dengan cara dibakar.

Usahatani manggis yang berkelanjutan secara lingkungan dalam pelaksanaannya sudah mengurangi penggunaan bahan kimia sampai minimum, melindungi sumberdaya alam seperti tanah, air, dan agen hayati yang memberikan sumbangan terhadap perlindungan modal alami. Pupuk sintetik dalam usahatani manggis yang berkelanjutan dapat digunakan untuk melengkapi input alami jika diperlukan.

Praktik usahatani dapat dikatakan berkelanjutan apabila memenuhi kriteria keberlanjutan berdasarkan tiga aspek yaitu aspek ekonomi, sosial dan lingkungan. Skor keberlanjutan usahatani manggis program Sertifikasi Prima dapat dilihat pada Gambar 1.

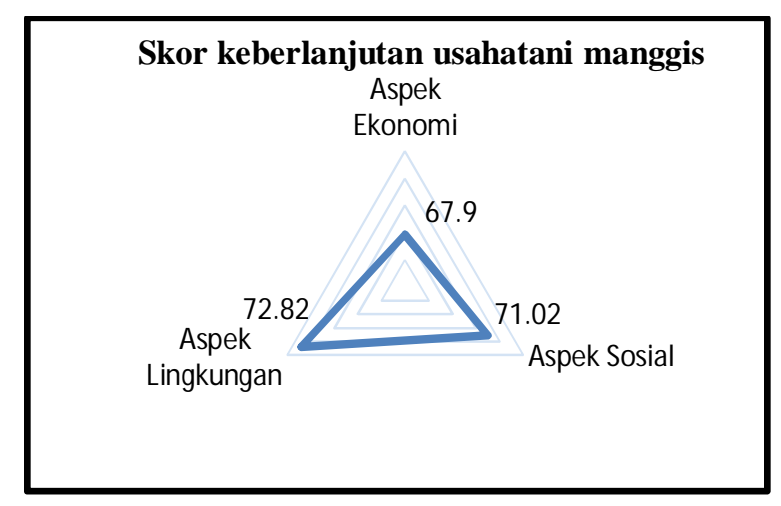

Gambar 1. Skor keberlanjutan usahatani manggis

Gambar 1 menunjukan bahwa skor keberlanjutan usahatani manggis program sertifikasi prima pada aspek ekonomi $(69,7 \%)$, sosial $(71,02 \%)$, dan lingkungan( $72,82 \%$ ) berada pada kategori cukup berkelanjutan. Hal ini berarti bahwa usahatani manggis program Sertifikasi Prima telah berkelanjutan. Prasmatiwi dkk (2010) dalam penelitiannya yang berjudul "Analisis Keberlanjutan Usahatani Kopi di Kawasan Hutan Kabupaten Lampung Barat dengan Pendekatan Nilai Ekonomi Lingkungan" menyatakan bahwa keberlanjutan usahatani kopi di kawasan hutan tergantung nilai eksternalitas. Berdasarkan analisis ekonomi ECBA, yaitu dengan turut memperhitungkan total nilai lingkungan dan sosial yang terjadi, besarnya NPV tergantung dari berapa besarnya biaya lingkungan dan biaya social sehingga secara tidak langsung aspek lingkungan dan sosial menjadi elemen penting dalam penilaian keberlanjutan usahatani suatu produk pertanian. 
Pelaksanaan usahatani manggis yang berkelanjutan diharapkan dapat menghasilkan produk yang aman dikonsumsi, jika produk pertanian yang dihasilkan telah aman dikonsumsi maka produk tersebut dapat memperoleh sertifikasi dari pemerintah. Semakin banyak produk pangan yang tersertifikasi maka pelaksanaan pertanian berkelanjutan secara umum dapat ditingkatkan di Indonesia. Sertifikasi dapat membantu petani yang tidak memperhatikan pola pertanian petani dengan baik. Selama ini petani hanya melakukan kebiasaan yang petani lakukan dalam pengolahan usahatani, tanpa mengetahui bahwa pengolahan usahatani yang telah dilakukan masih kurang tepat.

\section{KESIMPULAN}

Program sertifikasi Prima dapat memberi manfaat dalam aspek ekonomi, sosial dan lingkungan. Program Sertifikasi Prima untuk usahatani manggis di Pekon Terdana Kecamatan Kota Agung Kabupaten Tanggamus termasuk dalam indeks yang cukup berkelanjutan dengan skor indeks keberlanjutan ekonomi, sosial dan lingkungan secara berturut-turut sebesar 67,90, 71,02 dan 72,82 . Hasil perhitungan berdasarkan penerimaan atas biaya juga membuktikan bahwa perhitungan $\mathrm{R} / \mathrm{C}$ ratio dari budidaya manggis Program Sertifikasi Prima di Pekon Terdana Kecamatan Kota Agung Kabupaten Tanggamus memiliki nilai $>1$ yang berarti bahwa usahatani manggis memberikan keuntungan untuk dijalankan.

\section{DAFTAR PUSTAKA}

Arikunto S. 2002. Metodologi Penelitian Suatu Pendekatan Proposal. PT Rineka Cipta. Jakarta.

Badan Ketahanan Pangan Daerah Provinsi Lampung. 2015. Data Sertifikasi Produk Pertanian di Lampung. Bandar Lampung. Lampung
Balai Penyuluhan Pertanian Kecamatan Kotaagung. 2015. Laporan BPP Kecamatan Kotaagung Kabupaten Tanggamus. Tanggamus.

Anton D. 1996. Pengantar Metode Statistik. Jilid kedua. LP3ES. Jakarta.

Departemen Kesehatan. 2009. Profil kesehatan Indonesia Tahun 2008. Jakarta.

Kementrian Pertanian. 2014. Rancangan Rencana Strategis (Renstra) Kementerian Pertanian Tahun 2014-2019. Jakarta.

Kementerian Pertanian. 2017. Data Produk Ekspor-Impor Buah Indonesia Tahun 2015. Jakarta.

Mariyana, Prasmatiwi FE, dan Rosanti N. 2016. Manfaat program sertifikasi Prima-3 dan SLPHT dalam mengembangkan usahatani nanas yang berkelanjutan di Kecamatan Punggur Kabupaten Lampung Tengah. Jurnal Ilmu-Ilmu Agribisnis (JIIA), Vol. 4(1), Januari 2016. Pp: 56-66. http://jurnal.fp.unila.ac.id/ index.php/JIA/article/view/1215/1112. [27 Februari 2017].

Prasmatiwi FE, Irham, Suryantini A, dan Jamhari. 2010. Analisis keberlanjutan usahatani kopi di kawasan hutan Kabupaten Lampung Barat dengan Pendekatan Nilai Ekonomi Lingkungan. Pelita Perkebunan 26(1).57-69. https://www.ccrjournal.com/in dex.php/ccrj/article/download/117/pdf_31. [5 Juni 2018].

Setyo. 2009. Analisis Aliran Perdagangan Manggis Indonesia. Skripsi. Fakultas Ekonomi dan Manajemen. Institut Pertanian Bogor. Bogor.

Soekartawi. 1995. Analisis Usahatani. Universitas Indonesia (UI-Press). Jakarta.

Thamrin, SH Sutjahjo, C Herison, dan S Sabiham. 2007. Analisis keberlanjutan wilayah perbatasan Kalimantan Barat-Malaysia Untuk Pengembangan Kawasan Agropolitan. Jurnal Agro Ekonomi, 25 (2): 103-124. http://pse. litbang.pertanian.go.if/ind/pdffiles/JAE\%2025 -2a.pdf. [3 Oktober 2015]. 